\title{
Sinemada veya Netflix'te \\ Dijital İzleme Ortamları ve Yeni Alışkanlıklar \\ Bir Sosyal Ortam Olarak Sinema ve Film İzleme Pratiklerindeki Dijital Dönüşüm
}

\author{
Ayla Torun*
}

Özet

Yeni Medya'nın günlük yaşama getirdiği ve değiştirdiği alışkanlıklardan biri de film izleme alışkanlığındakideğişimdir. İnternetin bulunduğubirortama doğan bireylerinizlemealışkanlıklariönceki kuşaklardan farklılaşırken, dijitalleşmenin etkisindeki yetişkin bireylerin kültürel tüketim alışkanlıklarn da değişim göstermeye başlamıştır. Gündelik yaşamın bir parçası olan sinemada film izleme deneyimi, günümüz teknolojilerinin getirdiği imkanlarla evde izlenebilen bir yapıya dönüşmektedir. Televizyon ve yeni medya yayıncılığın etkileyerek yönlendiren Netflix, tüketici alışkanlıkların değiştirerek sinemayı da dönüştürür hale gelmiştir. İzleme edimi için esnek saatler ve seçenekler sunan dijital platformlar, web üzerinden izleme sağlayan siteler, uygulamalar giderek daha tercih edilir hale gelirken; dijital televizyon yayıncılar bu gelişmelerin ışığında hızla yeni yayın platformları üretmektedirler. İzleme alışkanlıkların değiştiren bu gelişmelerle, kentin gündelik yaşamı içinde sosyalleşme ve eğlence ortamı olarak önemli bir yer edinen sinema salonlan ve vizyon filmlerinin gösterimi konusu tartışmaya açık hale gelmektedir. Özellikle son yıllarda Netflix'in uygulamalarıla uluslararası festivallerin de tartışma konusu olan sinemada gösterim veya dijital yayın ortamında gösterim konusu, meseleyi mecra sorununun ötesine taşımaktadır. Çalışmada, dijital platformların film izleme alışkanlığı üzerinde yarattı̆̆ı değiş̧im ve bunun sinema filmleri ve bir sosyal ortam olarak sinema salonlarına etkisi, yapılan niceliksel alan araştırmastyla ortaya konmaktadır.

Anahtar kelimeler: Sinema, Netflix, Sinemanın Dijitalleşmesi, Dijital Yayın Platformları, Yeni Medya Yayıncılı̆̆ı, Film İzleyicisi

\footnotetext{
${ }^{1}$ Bu makaleye veri sağlayan “Sinemada veya Netflix'te Dijital İzleme Ortamları ve Yeni Alışkanlıklar” başlığı altında yapılan çevrimiçi araştırma sırasında katılımcılar bilgilendirilmiş, gönüllü onamları alınmıştır.

*Dr. Öğr. Üyesi, Nişantaşı Üniversitesi, İktisadi İdari ve Sosyal Bilimler Fakültesi, Istanbul, Türkiye

E-mail: aylatorun@gmail.com

ORCID : 0000-0003-1675-6366

DOI: $10.31122 /$ sinefilozofi.871301

Torun, A.(2021). Sinemada Netflix'te Dijital İzleme Ortamları ve Yeni Alışkanlıklar Bir Sosyal Ortam Olarak Sinema ve Film İzleme Pratiklerindeki Dijital Dönüşüm. Sinefilozofi Dergisi, Özel Sayı (3) .370-387. https//doi. org//10.31122/sinefilozofi.871301
}

Geliş Tarihi: 31.01.2021

Kabul Tarihi: 21.06 .2021 


\title{
At the Flicks or Netflix Digital Monitoring Environments and New Habits Cinema as a Social Environment and Digital Transformation of Film \\ Watching Practice
}

Ayla Torun*

\begin{abstract}
One of the habits that New Media brings and changed into daily life is the change in the habit of watching movies. While the viewing habits of individuals born in an environment where the Internet is available differ from previous generations, the cultural consumption habits of adult individuals under the influence of digitalization have also started to change. Not only television but also movie watching experience is realized new media tools through the Internet. While digital platforms that offer flexible hours and options for monitoring, sites that provide monitoring over the web, applications are becoming more and more preferred; digital television broadcasters are rapidly producing new broadcast platforms in the light of these developments. With these developments that changed the viewing habits, cinema halls, which have an important place as a socializing and entertainment environment in the daily life of the city, and the screening of vision films become open to discussion. Especially in recent years, the issue of screening in the cinema or the screening in digital broadcast platforms, which has been the subject of discussion in international festivals with Netflix's applications, takes the issue beyond the medium problem. In the study, the change created by digital platforms on the habit of watching movies and the effect of this on cinema films and movie theaters as a social environment are revealed by the quantitative field research.
\end{abstract}

Keywords: Cinema, Netflix, Digitalization of Cinema, Online Streaming Platforms, New Media Broadcasting, Film Audience, Audience Research

\footnotetext{
*Res. Asst., Nişantaşı University, Faculty of Economıcs, Admınıstratıve and Socıal Scıences, Istanbul, Turkey

E-mail: aylatorun@gmail.com

ORCID : 0000-0003-1675-6366

DOI: 10.31122/sinefilozofi.871301

Torun, A.(2021). Sinemada Netflix'te Dijital İzleme Ortamları ve Yeni Alışkanlıklar Bir Sosyal Ortam Olarak Sinema ve Film İzleme Pratiklerindeki Dijital Dönüşüm. Sinefilozofi Dergisi, Özel Sayı (3) .370-387. https//doi. org//10.31122/sinefilozofi.871301
} 


\section{Extended Abstract}

One of the habits that New Media has brought and changed into daily life is the change in the habit of watching movies. While digital platforms that offer flexible hours and options for monitoring, sites that provide monitoring over the web, applications are becoming more and more preferred; digital television broadcasters are rapidly producing new broadcast platforms in the light of these developments. The cinema halls, which have an important place in the daily life of the city as a socializing and entertainment environment, and the screening of vision films are becoming open to discussion. Information technologies and new media are closing the person took out by Lefebvre back to home again.

Netflix, which influences television and new media broadcasts; transformed the cinema by changing consumer habits. In the study, the changing habits of the cinema audience and the differentiation of expectations in the movie watching experience are revealed by a quantitative field study conducted on 127 people. The research, which reveals the current position of Netflix through the eyes of the audience, provides the opportunity to determine the effects of this digital platform, which has become the object of desire of consumption, on the cinema industry.

The convergence that emerged as a result of the advancement in information technologies bringing the Internet and television together made the cinema industry transform. The transformation of the film industry and the digitalization of cinema have paved the way for digital platforms to replace movie theaters. Although the idea that it is not possible for the screen to replace the movie theaters in the movie viewing experience continues to prevail, this situation cannot change the fact that a serious change has taken place. While many digital platforms produce their own TV series, the Netflix platform also produces movies and deconstructs the experience and tradition of watching movies by broadcasting the movies on its own platform simultaneously with the release date.

In parallel with the developments in new media publishing, the digitalization of the cinema leads to the increase of digital platforms, which are international online content producers. Although television series are produced on the other platforms, there is no "intervention" such as the simultaneous screening of the movie that is released in the cinema, except for the subsequent screening as in film production and traditional TV broadcasting. The fact that a digital platform produces its own films and broadcasts itself, usually without being screened in the cinema, or broadcasting a movie that is released simultaneously on its own platform shakes the structure of the cinema's distribution channel.

As understood from the rules of the world's leading film festivals regarding the distribution and display of the films that will participate in the festival, it tries to maintain and support independent cinema together with its own country's cinemas. Digital platforms emerging with the developments in new media broadcasting and Netflix, which is open to use worldwide, cause significant changes in the production, distribution and display processes of the cinema industry and the film industry. It is observed that Netflix, interfering with the field with the simultaneous broadcasting of various movies on Netflix while they are still being shown in theaters, has changed the behavior of the audience as an object of cultural consumption.

The argument that new media technologies turn the audience from a passive to an active position with the possibilities they produce is open to interpretation as an increase in the passivity of the receptor when the subject is considered from a sociological perspective. Even though the function of movie theaters has been questioned in various periods during the 125 years of cinema's existence, the effect of today's digital platforms is more destructive than all. However, as revealed by the data obtained from the research; The desire of the audience following the cinema to watch movies with high sound quality on the big screen with care and attention, depending on the nature of the film, still continues to exist effectively. Cinema maintains its existence as a means of socialization in daily life. It is still possible to see the film viewer's act of watching movies on other platforms as a complement to the cinema experience. From this point of view, this research has once again revealed that Netflix is not an alternative to movie theaters, but a platform that offers more options for the cinema audience. 
On the other hand, the realities such as the comfort zone created by the experience of watching movies at home, ease of access, independence of time, economical suitability, variety of film options, the possibility of giving up or changing the movie without paying a price, show the potential that will continue to shake the position of the experience in cinema. 


\section{“Sinema eğlendirir ve zenginleştirir!”}

Louis Lumiere, 1896

\section{Giriş}

Henri Lefebvre'nin gündelik yaşamın üretimine dair sorgulamalarına göre, şehirdeki gündelik yaşamı üreten mekanlardan biri de sinemadır. Marxizmin eksikliklerini tamamlamak ve köktenci çözümler önermek üzere gündelik yaşamı inceleyen ve çalışmalarını gündelik yaşam olgusunun sosyolojisini üretmeye adayan Lefebvre; zaman, mekan, şehir ve beden kavramlarını irdeleyerek, felsefe, sanat ve bilim karşısında aleladeleşen gündelik yaşamı "sanat" olarak ele alır. Gündelik yaşamın merkezi olarak şehri benimseyen Lefebvre'ye göre "şehir, bedende konuşur, dinlenir, oluşur ve hatta dönüşür" (Lefebvre, 2004, pp. 87-89). Ona göre, asıl olan evden şehre kayıştır. Çünkü bireysel varoluşu ve bilinci açığa çıkarabilecek ve sembolize edebilecek olan yer ev değildir; yaşadı ̆̆1 şehirdir (Lefebvre, 1996, pp. 149150). Gündelik yaşamın bir parçası olan ve şehri bir beden olarak yaşatan olgulardan biri olan sinemada film izleme deneyimi, günümüz teknolojilerinin getirdiği imkanlarla evde izlenebilen bir yapıya dönüşmektedir. Enformasyon teknolojileri ve yeni medya, Lefebvre' nin evden dışarı çıkardığı bireyi yeniden evine kapatmaktadır.

Dönüşümü devam eden ideolojik aygıtlardan (Althusser, 1970) olan kitle iletişim araçları, teknolojik gelişim içinde yeni medya araçlarına dönüşürken, kitlesellik niteliğini bireyselliğe dönüştürerek yeniden inşaa etmektedir. Gündelik hayatın çözümlenmesinde toplumun "tüketim" ile ilişkisine vurgu yapan Lebebvre'e göre toplum, özellikle "bir ideoloji kadar değer kazanmış olan reklamcılık sektörü" aracılığıyla tüketime yönlendirilmektedir. Lefebvre, bu toplumu "Bürokratik Yönlendirilmiş Tüketim Toplumu" olarak adlandırmıştır. Kültürel alanın kurumsallaşması, gündelik hayatın bürokratikleşmesinin ilk adımıdır. Bu, XX. yüzyılın başlarından itibaren gelişip serpilmeye başlayan kültür ve bilinç endüstrilerinin (gazeteler, moda, sinema, reklâm endüstrisi, kültür aracıları, v.s.) işbirliğiyle şekillenen yeni bir toplumsal kategorinin, sonrasında tüketim toplumuna varacak olan uzantılarıdır (Lefebvre, 1998, p. 85). Bu doğrultuda günümüz toplumunun izleme edimiyle ilişkisini, iki düşünürün kavramları ışığında değerlendirmek olasıdır.

1960'l1 yılların sonlarından itibaren kapitalizmde üretimin merkezi bir kavram olarak önemini yitirdiği ve artık pek çok değerlendirmenin tüketim merkezli söylemler üstünden yapıldığını söyleyebiliriz. Baudrillard'ın ifadesiyle (2005, p. 63), her ne kadar üretimin ufku yok olmaya başlasa da sözün, cinselliğin ve arzunun ufku onun yokluğunu hissettirmemektedir. Tarihsel süreç içinde teknolojinin kendini yenileme hızındaki artışa paralel olarak sermaye devir hızını yükseltmek için malların kullanım sürelerini alabildiğince kısalttığından, mallar sık sık "kullanımdan düşmektedir". Nesnelerin kullanım süreleriyle oynandığından doğal olarak arzunun toplumsal ifadesi olan motivasyonlar yönlendirilmektedir. Bu arzu stratejisi, nesnelerin "manevi" yıpranma ve kullanımdan düşme süresinin kısalması için gereksinimlerin eskimesini ve yeni gereksinimlerin onların yerini almasını (Lefebvre, 1998, pp. 85-86) gerekli kılmaktadır. Sinemanın yerini dijital platformlar ve Netflix'in alması, teknolojinin de etkisiyle gündelik yaşam ve tüketim alışkanlıklarındaki değişimin bir sonucudur. Bu değişimde, "arzunun toplumsal ifadesi olan motivasyonun" teknolojik gelişmelerin etkisiyle belirleyici olduğu aşikardır. Yeni medya araçlarıyla birlikte kültürel tüketim alışkanlıkları dönüşüm geçiren toplumun izleme edimini yeniden üreterek, Netflix'i sinema kültüründeki değişimin motivasyon öznesi haline getirdiğini söylemek mümkündür.

Teknolojideki gelişmelerle birlikte, film izleme deneyimini sinema salonlarının dışına çıkaran televizyon, DVD gibi araçları, günümüzde dijital yayın platformları izlemektedir. İnternet ve dijital teknolojilerin birleşimiyle, film üretim, dağıtım ve gösterim süreçleri dijitalleşirken; tüketici konumundaki izleyici ise bu dijital dönüşüme seyir deneyimindeki 
tercihleriyle yön vermektedir. Bu teknolojik dönüşümün ortaya çıkardığı dijital platformların, sinemanın yerini almak, seyirci sayısını azaltmak gibi etkileri dile getirilirken; daha çok filme ulaşma işlevi sayesinde sinemayı destekleyici etkide bulunduğu da savunulmaktadır. Netflix, ürettiği "özel içerikler" ile film yapım sürecini desteklerken, diğer yandan da "sinemada gösterim yapmayan filmler" olgusunu ortaya çıkarmıştır. Sinemanın dağıtım-gösterim ayağını sekteye uğratan bu durum, özellikle film festivallerinin odaklandığı bir husus olmuştur. Sinemanın sanat olarak onaylanma ihtiyacının öznesi olan film festivallerinin, Netflix vb dijital platformların yapımlarına karşı tutumları, genellikle festivale kabul etmeme yönündedir.

Abone sayısının artması ve giderek popülerleşmesiyle, Netflix ile ilgili gündelik yaşam literatürüne giren bazı kavramlar üretilmiştir. Bunlardan "Netflix effect/etkisi" yeni medya yayıncılığının özellikleri olan çoklu ortam sağlama, kitlesizleştirme, bireyselleştirme ve mekandan bağımsızlaştırma gibi unsurları kapsamaktadır. "Netflix etkisi" söyleminin kullanıldığı etkilerden biri olan İngilizce adıyla "binge-watching" ya da yaygın kullanımda "Netflixing" denilen aşırı seyir, bir TV serisinin bölümlerini art arda tek bir oturumda ve kısa zamanda izleme davranışıdır. Netflix tarafından yapılan bir ankete katılanların \%61'i düzenli olarak aşırı seyir yaptıklarını ve \%73'ü de TV içeriğini aşırı izleme konusunda olumlu duygulara sahip olduklarını söylemektedir (akt. Kelly, 2013).

Kitlesizleşme ve bireyselleşme ile yaşamını dar bir mekâna sığdıran (eve kapanan) insan, mutluluğu ya da arzunun toplumsal ifadesi olan motivasyonu uzun saatler izlenen bir yapımın sonunda elde edilen tatmine bağlamaktadır. Böylece kişi, Sennett' in ifade ettiği gibi (2016, p. 11); sadece en yakın aile ve arkadaş çevresiyle ilişkisini sürdürür. Diğer insanların varlığı ya da sorunlarına ilgisiz bir halde, yalnız kendisi için var olur. Böylece kamusal alandan, gündelik yaşamın bedeni olan şehirden, sosyalleşme ortamı olan sinema gibi ortamlardan uzaklaşır.

Televizyon ve yeni medya yayıncılığını etkileyerek yönlendiren Netflix, tüketici alışkanlıklarını değiştirerek sinemayı da dönüştürür hale gelmiştir. Çalışmada, yeni medyanın etkisiyle ortaya çıkan dijital yayın platformları ve Netflix incelenerek, sinemanın dağıtım-gösterim ayağındaki değişim doğrultusunda film festivallerinin bu gelişmelere karşı aldığı pozisyon ele alınmış ve izleyicilerin sinemada veya Netflix'te film izleme tercihlerini gerekçeleriyle ortaya koyan bir niceliksel alan araştırması ile devam edilmiştir.

Sinema izleyicisinin alışkanlıkları ve film izleme deneyimine dair beklentilerdeki değişimi ortaya koyan araştırma; Netflix' in, izleyicinin sinemaya gitme davranışını değiştirdiği ve evde izleme ortamlarının tercih edilir hale geldiği tezini sorgulamıştır. Netflix'in bugünkü konumunu izleyici gözünden ortaya koyan araştırma, tüketimin arzu nesnesi haline gelmiş olan bu dijital platformun sinema sektörüne etkilerini tespit etme imkanı sağlamaktadır.

\section{Yeni Medyanın Etkisi}

Yeni medya teknolojilerinde ortaya çıkan gelişmeler yayıncılık alanında önemli değişimlere yol açarak "yeni medya yayıncılığı" alanının ortaya çıkmasını sağlamıştır. İnternet öncesi dönemde ve Web 1.0 döneminde geleneksel kitle iletişim araçları ile sürdürülen yayınların, Web 2.0'de ses, video, müzik içeriklerin web'de yayınlabilir hale gelmesiyle online yayıncılığın önünü açarken, Web 3.0 ile birlikte dijital yayınlara evrilmiş ve televizyon sektörü ile rekabetin hızla arttığı dijital televizyon platformlarını yaratmıştır. Önceleri telifsiz/korsan film yayınlama ekseninde film sektörünü etkileyen İnternet, zamanla izleme platformu olarak televizyon yayıncılığının, ardından sinemanın konumunu derinden etkilemektedir.

Bilgisayar, akıllı telefon, tablet gibi yeni medya teknolojileriyle medyanın izlenebilirlik özelliği kişisel olarak programlanabilir hale gelirken; yeni medyanın etkileşim, yöndeşme ve sayısallaşma özelliklerinin etkisiyle gazete, televizyon yayınları, radyo yayınları ve sinema filmleri gibi içerikler İnternet aracılığıyla dijital ortama taşınmıştır.

Varoluşu teknolojideki gelişmelerle başlayan film üretimi ve gösterimi, İnternet'in var olduğu bir ortamda enformasyon ve telekominikasyon teknolojilerindeki gelişimlerle birlikte 
dijital dönüşüm yaşamış; yeni medyanın yöndeşme özelliği ile film ve televizyon izleme eyleminin iç içe geçtiği bir aşamaya evrilmiştir. Analog kamera ile peliküle kayıt edilen ve çoğaltılarak dağıtılan konvansiyonel film üretim modeli, dijitalleşme ile yerini dijital kamera, kurgu, özel efekt, dijital kopya ve İnternet üzerinden tek merkezden dağıtılarak gösterime girmeye bırakmıştır. Televizyondan sonra video kaseti, VCD, DVD, Blu-ray aşamalarında geçen sinema salonu dışında film izleme deneyimi ise artık dijital platform üyelikleriyle yüksek görüntü kalitesinde, sınırsız ve süresiz izlenebilir hale gelmiştir. Dijital film üretim süreci, yeni medya teknolojilerinin vasıtasıyla sinemayı, film üretiminden gösterim sürecine kadar değişime uğratmaktadır.

Enformasyon teknolojilerindeki gelişimin İnternet ile televizyonu bir araya getirmesiyle ortaya çıkan yöndeşme durumu, sinema sektörünü de dönüşür hale getirmiştir. Film endüstrisindeki dönüşüm ve sinemanın dijitalleşmesi, dijital platformların artık sinema salonlarının yerini almasının önünü açmıştır. Her ne kadar film izleme deneyiminde sinema salonlarının yerini ekranın alması mümkün değil düşüncesi hakim olmaya devam etse de bu durum ciddi bir değişimin yaşandığ gerçeğini değiştirememektedir. Pek çok dijital platform kendi dizi filmlerini üretirken, bunlardan Netflix platformu sinema filmleri de üretmekte ve sinema filmlerini vizyona giriş (gösterim) tarihleriyle eş zamanlı olarak kendi platformunda yayınlamasıyla, sinema izleme deneyim ve geleneğini yapı bozumuna uğratmaktadır. Film festivallerinde de tartışmaya yol açan bu durumla birlikte geleneği uzun yıllara dayanan film festivalleri çeşitli kararlar almışlardır. Bu nedenle, sinemanın önemli yapıtaşlarından olan film festivallerinin, Netflix ve diğer dijital platformların yapımlarına karşı yaklaşımları çalışmada ele alınmıştır.

\section{Dijital Platformlar ve Netflix}

Yeni medya yayıncılığındaki gelişmelere paralel olarak sinemanın dijitalleşmesi, uluslararası online içerik üreticileri olan dijital platformların giderek artmasına yol açmaktadır. Yeni kurulan teknoloji temelli firmalara geçmişin yayın kuruluşları ve film yapım şirketlerinin eklenmesiyle, Netflix ile birlikte dijital yayın platformları Amazon Prime, Apple TV, Hulu, Sony, HBO, BBC IPlayer, Disney+ gibi firmalar rekabete girmişlerdir.

2020 yılının sonunda Netflix'in dünya çapında 190 ülkede 203.66 milyon kayıtlı abonesi bulunmaktadır. Bir Netflix hesabını birden fazla kişinin kullandığı göz önünde bulundurulduğunda, dünya genelinde Netflix kullanan kişi sayısının bu değerin birkaç katı olduğu söylenebilir. 2020 yılında Netflix'in yıllık geliri 25 milyar dolar, yıllık karı ise 4,6 milyar dolardır (Netflix, 2021).

Netflix'in abonelerine sunduğu özellikleri; Aylık erişimi, yayın kalitesine göre 480p standart (SD) - 18 TL, 1080p yüksek (HD)- 30 TL ve 4K+HDR ultra yüksek çözünürlük (UHD) yayın $42 \mathrm{TL} /$ aylık fiyatlarla abonelere sunulmaktadır. Bilgisayar, akıllı TV, akıllı telefon, tablet, medya oynatıcı ve oyun konsolları gibi tüm yeni medya araçları üzerinde çok sayıda cihazda İnternet bağlantısı ile sınırsız izleyebilme, abonelik süresi için taahhüt olmaksızın istenilen zamanda iptal edebilme, zaman ve mekandan bağımsız her yerde izlenebilme, reklamsız yayın yapılması, son olarak eklenen çevrimdışı izlemek için indirip kaydederek izleme özelliği öne çıkan özellikleridir. Seslendirme ve altyazı olarak çoklu dil seçenekleri bulunmaktadır. Dünyanın birçok yerinde izleyiciler, kendi ana dilleriyle Netflix programlarına erişim sağlayabilmektedirler. Her dijital platformda olduğu gibi durdurma ve ileriye veya geriye alma, algoritmalarla kişiselleştirerek daha önce izlediklerine yakın türdeki içerikleri ön plana çıkararak önerme gibi standart dijital yayın özellikleri ve uzun saatleri TV karşısında geçirmek istemeyenler için daha kısa ve makul dizi süreleri sunmaktadır. Ancak ayrıştığı en önemli özelliği "bağımsız" ve "yerel" içerik de üretiyor olmasıdır.

1997 yılında DVD kiralama firması olarak kurulan firma, 1999'da aylık DVD aboneliği sistemine geçmiştir. 2007 yılında kullanıcılara "anında izle" sloganıyla kendi bilgisayarları 
üzerinden film ve dizileri izleme imkanı sunmaya başlamıştır. 2012 yılında, ilk kez kendi orijinal televizyon dizisinin yayınına başlaması, platformun ön plana çıkmasının başlangıcı olur (Osur, 2016, pp. 21-22). Netflix diğer dijital platformlar ile kıyaslandığında, iş modeli olarak ürettiği "özel içerikler" ile ayrışmaktadır. Netflix, çoğu diğer platformlar gibi sadece gösterim yapmamakta, kendisine özel içerik üretmektedir ve bu yönüyle sinema sektörüne kaynak aktararak yatırım da yapmaktadır. Diğer adı geçen platformlarda da televizyon dizileri üretimi yapılmakla birlikte, film yapımı ve geleneksel TV yayıncılığındaki gibi sonradan gösterim dışında, sinemada vizyona giren filmin eşzamanlı gösterimi gibi bir "alana müdahale" sözkonusu değildir.

\section{Festivaller ve Netflix}

Dijital platformlarda film izleme deneyiminin ve Netflix'in tüketici davranışlarının da değişmesine yol açan en önemli etkisi, halihazırda sinemada gösterime olan ilginin azalması varsayımıyla, sinema salonlarına yönelmektedir. Sinema endüstrisinin işin gösterim yönüyle ilgili kuralı, filmlerin önce sinema salonlarında gösterilmesi ve film için sinemaya gelen seyirci kitlesinin tamamlanması sonrasında bireysel kullanım için DVD ya da benzeri yöntemle çoğaltılması, son olarak da ekonomik ömrünü tamamlarken bir televizyon kanalına satılarak halka açı gösterilmesi şeklindedir. Televizyonun yaygınlaştığı yıllarda da sinema sektörü bu yenilikten etkilenerek seyirci kaybetmiştir. Arkasından gelen DVD döneminin sarsıcı etkileri olmakla birlikte, bahsi geçen kural çerçevesinde her bir mecra kendi varlığını sürdürmüştür. Ancak bir dijital platformun kendi yapımı filmleri üreterek, genellikle sinemada gösterim olmaksızın kendisinin yayınlaması veya vizyona giren bir filmi eş zamanlı olarak kendi platformunda yayınlaması, sinemanın dağıtım kanalındaki bu yapıyı sarsmaktadır.

Çalışmanın bu aşamasında, sinemada film izleme geleneğinin törensel yapıtaşlarından olan film festivallerinin dijital platformlara yaklaşımının incelenmesi gereği hissedilmiştir. Film endüstrisinin üretim, dağıtım, gösterim sistemindeki dengeyi etkileyen bu "alana müdahale" durumu, geleneği uzun yıllara dayanan film festivallerinde de tartışma konusu olmuştur. Netflix özel yapımı olan filmlerin, sinemada hiç vizyona girmeden Netflix'te gösterilmesi ve festivallere başvurması, festival ölçütlerindeki başlıca değişen unsurdur. Öte yandan, bazı yapımların sinemadaki gösterimleriyle eş zamanlı olarak Netflix'te, yani çoğu festivallerin genel kriterlerine göre toplu izlemeye açık televizyon yayını niteliğindeki bir mecrada gösterime girmesi, eserin sanatsal niteliğini alışılan düzlemden çıkarmaktadır. İnternet ve yeni medya teknolojilerin ilişkili olduğu alanlara etkisi, bu şekilde kendisinden önceki iş yapış modellerinin yerine yenisini koymasıyla kendini göstermektedir. Ancak, film festivalleri açısından değerlendirildiğinde, Netflix ve benzeri dijital platformların adımlarına karşın, festival ruhunu korumaya yönelik tedbirler aldığı görülmektedir.

Netflix yapımı filmlerin Akademi (Oskar) Ödülleri'ne aday olması üzerine başlayan tartışmalarda Yönetmen Steven Spielberg; "Netflix sinemanın otantik tarafını mahvediyor, sinema salonları her daim var olması gereken yerlerdir" yorumunu yapmıştır (Barfield, 2018). Steven Spielberg' in, çevrimiçi içerik sunan Netflix'e ait filmlerin Oscar'a aday gösterilmemesi teklifi reddedilmiştir. ABD Adalet Bakanlığı da internet üzerinden yayınlanan filmlerin Oscar adaylıklarının kabul edilmemesinin tekelcilik karşıtı yasalara aykırı olduğunu söyleyerek Akademi Kurulu'nu uyarmıştır. Netflix yapımı olan ve üç haftalık gösterim süresinden sonra Netflix'te abonelerle paylaşılan Roma (Alfonso Cuarón, 2018), 10 dalda Oscar'a aday gösterilmiş ve film 3 ödül kazanmıştır. Roma'nın ve diğer filmlerin Oskar ödülü alması sinema sektöründeki değişimin göstergelerinden biridir.

Oscar ödüllerine katılım için uygulanan maddeye göre, bir filmin aday olabilmesi için Los Angeles'taki bir ticari sinema salonunda en az 7 gün süreyle, günde en az üç kez gösterilmesi ve gösterimlerden bir seansın mutlaka akşam saatinde yapılması gerekmektedir (Rule 2. 2 c, d). Yine bu maddeye göre, bir filmin ilk halk gösterimi ve dağıtımı sinema salonları dışında internet erişimi, yayın platformu, kablolu televizyonda veya DVD ortamında yayınlanırsa 
Oscar adayı olamaz. Ancak Los Angeles sinemalarındaki ticari gösterimlerinin ilk gününden itibaren bu gibi mecralarda -video içerik sağlayıcısı Netflix gibi platformlarda- yayınlanmaları uygundur (Rule 2. 3). Yalnızca 2021 yılında 93. Ödüller için, önceden planlanmış bir sinema gösterimi olmakla beraber Mart 2020'den itibaren koronavirüs salgınında sinema salonlarının kapalı kalması nedeniyle, sinemalarda ticari gösterim yapamadan video içerik platformlarında gösterilen filmlerin adaylığının kabul edileceği açılanmıştır (Academy Foundation, 2021).

Cannes Film Festivali'nde de benzer tartışmalar yaşanmıştır. Ancak, Fransa kanunlarına göre, sinemalarda gösterilen bir filmin ancak 36 ay yani üç y1l sonra dijital ortamda ve Internet üzerinden yayınlanmasına izin verilmektedir. Cannes Film Festivali'nde yarışmacı olan her uzun metrajlı film, medya kronolojisi kurallarına ilişkin Fransız mevzuatı uyarınca Fransa'da sinemalarda gösterilmiş olmalıdır (article 3.7). Ayrıca, İnternette sergilenmemiş filmler olması kuralı vardır (article 3.4) (Festival de Cannes, 2021). Bu maddelerle, Netflix veya diğer platformlarda yayınlanan herhangi bir filmin Palm D'Or (Altın Palmiye ödülü) için yarışması engellenmiştir. Venedik Uluslararası Film Festivali'nde de İnternette herhangi bir şekilde ticari dağıtımı veya gösterimi bulunmayan filmlerin resmi seçkiye dahil edilmektedir. (La Biennale Di Venezia, 2021).

Berlin Uluslararası Film Festivali'nde, Yarışmaya katılacak Almanya yapımı filmlerin daha önce hiçbir gösteriminin yapılmamış olması kuralı vardır. Tüm yarışmacı filmler ne televizyonda ne de internette ve digital platformlarda sunulmamıs olmalıdır (Competition Regulation 1. Eligibility) Alman filmleri dışındaki filmlerin bir sinemada ticari gösterimi ve menşe ülkede bir festival katılımı kabul edilmektedir. Aynı durum çevrimiçi bir festivale katılım için de akışlara yalnızca menşe ülkede erişilebilir olduğu sürece ("coğrafi engelleme" teknolojisi aracılığıyla) geçerlidir (General Regulations 2.1). Almanya yapımı dişındaki filmlerde televizyon, İnternet veya digital platformlarda yayınlanan bir filmin internetteki kullanılabilirliği yalnızca filmin menşe ülkesiyle sınırlıysa, festivalin Panorama bölümüne kabul etmektedir (Panorama Regulation 1. Eligibility), (Berlinale, 2021). Toronta Uluslararası Film Festivali, Kuzey Amerika'da sinemada gösterilmiş ve televizyonda, digital platformlarda veya çevrimiçi olarak yayınlanmış filmleri değerlendirmeye kabul etmemektedir (TIFF, Rules\&Term).

Dünyanın önde gelen film festivallerinin, festivale katılacak filmlerin dağıtım ve gösterimiyle ilgili kurallarından da anlaşıldığı gibi, kendi ülke sinemalarıyla birlikte bağımsız sinemayı bir sanat dalı olarak sürdürmek ve desteklemeye çalışmaktadır. Bununla birlikte, ana akım sinemanın temsilcisi olan Oscar Ödülleri'nde, ülke felsefesiyle eşleşen bir bakış açısı görülmektedir. Sinemanın bir sanat eseri olarak sergilenme koşullarını muhafaza etmek ve sektörünün dağıtım ve gösterim tarafının uğradığı ekonomik kayıp nedeniyle festivaller bu tedbirleri alırken; Netflix'in özgün ve yerel içerikler üretmesi, film üretim tarafında ekonomik kazanç ve sektörün gelişimini destekler nitelikte değerlendirilmektedir. Netflix'in aktardığı kaynak yeni ve bağımsız yapımların üretilmesine firsat verirken, bu kaynakla ana akım sinemada yer bulamayacak filmlerin yapılmasını film endüstrisine katkıda bulunmak olarak görenler bulunmaktadır. Faaliyet gösterdiği ülkelerdeki ürettiği yerel yapımlar için de benzer yaklaşım gözlemlenebilmektedir. Aveyard'a göre; "Prodüksiyon tarafına yapılan bu yeni müdahale sinemada gösterime girmeyen ancak, o filmlerin sahip olduğu kadar paraya sahip olan filmler yapılması anlamında dinamikleri değiştirmektedir. Kültürel ve ekonomik değerlerinin devamlılığını sağlayan bağımsız ama yine de kaliteli yapımlar, endüstri, çeşitlilik, stüdyo sistemine bağlı güç dağılımı yönünden değerlendirildiğinde, bu filmler sektöre daha geniş katılım için daha fazla alan sağlamaktadır" (Robins, 2018). Ancak, bu yapımların bedelinin zaten abonelik usülüyle elde edilen gelirden, yapım öncesinde toplandığı düşünüldüğünde, Netflix'inki vizyon kaygısı olan yapımlara göre risksiz bir film üretim biçimi olarak sinemanın üretim dinamiklerinden ayrışmaktadır. 


\section{Yöntem ve Araştırma}

$\mathrm{Bu}$ araştırmada, dijital platformların ortaya çıkmasıyla birlikte, sinema salonunda film izleme alışkanlığının yerini çok sayıda film yayınlayan Netflix ve benzeri platformlara bırakıp bırakmadığı tespit edilmeye çalışılmıştır. Araştırma, Nişantaşı Üniversitesi Etik Kurulu'nun 5.3.2021 tarih, 2020/4 sayılı kararıyla yapılmıştır.

İnternet üzerinden izleme ve dijital platformların izleyici davranışları üzerindeki etkileyen çeşitli araştırmalar yapılmaktadır. İzleme deneyimine dair sosyal modelleme yapan Anghelcev ve diğerlerinin araştırması (2020), aşırı seyreden ABD üniversite öğrencilerinin motivasyonunun gündemi kaçırmamak ve kanaat önderi olma pozisyonlarını korumak olduğunu ortaya koymaktadır. Araştırmalarında üniversite öğrencilerinin izledikleri içeriklerle sosyal yaşamlarında varlık gösterdiklerini saptamıştır. Karaduman (2018), genç sinema izleyicilerinin internet üzerinden film izleme alışkanlıkları ve motivasyonunu ele almıştır. Y kuşağı gençler üzerinde araştırma yapan Diker (2019), genç kuşakta tüketim kültürü ve seyir deneyimleri arasındaki ilişkiyi değerlendirmiştir. Medin (2018), izleyicilerin mobil ve ekran temelli bir seyir deneyimini tercih ettiklerini ortaya koymaktadır. Anadol'un çalışmasında (2020) genç izleyicileri sinema salonunda ve sonrasında sinema salonu dişında dijital ortamlar üzerinden film izlemeye yönlendiren unsurlar karşılaştırılmaktadır. Anket ve/ veya derinlemesine görüşme yöntemlerinin kullanıldı ̆̆ı bu çalışmalarda, yeni kuşak izleyiciler olan üniversite öğrencilerinin izleme davranışları ortaya konmaktadır. Öte yandan, 2020 yılından itibaren günlük yaşamı kesintiye uğratan Covid-19 pandemisi, dijital platformlarda seyir ve aşırı seyir davranışının yaygınlaşmasına yol açarken konuyla ilgili pek çok akademik çalışma ve araştırma yapılmıştır. Bu araştırmalar genellikle izleme edimini seyir süresi ve bundan sosyol ve fiziksel etkilenme yönüyle ele alırken; bu çalışma dijital izleme ortamları ve Netflix'in, seyircinin sinema ile olan ilişkisini nasıl etkilediğine odaklanmaktadır.

Çalışmanın araştırma evreni Türkiye sinema izleyicileri, örneklemi ise 30-55 yaş grubundaki yetişkinler olarak belirlenmiştir. Örneklem olarak 30-55 yaş grubunun belirlenmesinin nedeni, bu yaş grubundaki bireylerin, yaşları itibarıyla internet olmayan dönemde sinema izleyicisi olma potansiyelleridir. Böylelikle, İnternet öncesi dönemde sinema izleyicisi olduğu varsayılan ilgili yaş grubu yetişkinlerin tercihlerini Netflix'ten yana değiştirme oranları -pandemi koşullarından bağımsız olarak- ve buna neden olan etkenlerin ortaya konması amaçlanmıştır.

TÜİK verilerine göre 2019 yılında Türkiye' de, sinema salonundan film izleyen izleyici sayısı 56 milyon 479 bin 209 kişidir. Bu sayı, birim bileti satışı verisi ifade ettiği için, izleyici kitlesinin net sayısını ortaya koyamamaktadır. Yani, bir kişinin yıl içinde birden fazla filmi izlediği kabulüyle, bu veri "izleyici sayısı" değil, "izleme sayısı" olarak değerlendirilmelidir. 2019 yılında sinemada film izleme sayısı 2018 yılına göre \%12.8 azalmıştır (TÜİK, 2020).

$\mathrm{Bu}$ araştırmanın hipotezi, Netflix'in sinema izleyicisinin sinemaya gitme davranışını değiştirerek, evde izleme ortamlarının tercih edilir hale geldiği tezini sorgulamaktır. Karşıt hipotezi ise genel kanının aksine, dijital platformların sinema izleyicisi üzerinde davranış değişikliği yaratmadığı ve sinema salonlarında izleme ediminin devam ettiğidir. TÜİK'in ilgili verisiyle ortaya konan sinemada film izleme sayısındaki azalmada, sinema izleyicilerinin değişen tüketim alışkanlıklarının ve film izleme deneyimindeki beklentilerinin farklılaşması etken olarak görülmektedir. Bu varsayımın etkenleri, 127 kişi üzerinde yapılan bir niceliksel alan araştırması ile ortaya konulmuştur. Araştırmaya davet edilen katılımcılar, İnternet'in ve yeni medya teknolojilerinin henüz aktif olarak gündelik yaşam alışkanlıklarını etkileyecek kadar kullanılmadığı dönemde yetişen, üniversite mezunu yetişkinlerdir. Bunun nedeni, filmi sinemada deneyimleme alışkanlığına sahip oldukları varsayılan bu kişilerin izleme davranışlarında, dijital platformların ortaya çıkmasıyla yaşanan değişimi tespit edebilmektir. İnternet çağında yetişen yeni neslin izleme alışkanlıkları zaten yeni medyanın sağladığı imkan ve teknolojilerle oluştuğundan, yaş grubu olarak bu ayrıştırmaya gidilmiştir. Araştırma, 
örneklemdeki bilgilerden yararlanarak, evrenin özelliklerinin tahmin edilmesini yönelik metodlardan olan çıkarımsal istatistik yöntemiyle yapılmıştır.

Araştırmaya katılan denekler 30 - 55 yaş arasında, üniversite mezunu, profesyonel meslek yaşamı olan bir kitledir. Seçkisiz olmayan örnekleme modelinde, tabakalı amaçlı örnekleme deseni oluşturulmuştur. Örneklemin bu şekilde belirlenme sebebi, katılımcıların belirli bir beğeni düzeyinde film izleyen kişilerden oluşması hedefidir. Bilimsel araştırma için baz eleman sayısı olan 30'dan büyük örneklem büyüklügüu belirlenmiştir. Buna göre kadın / erkek, eğitimli / meslek sahibi sinema izleyicisi olarak her kategoriden en az 30 eleman genişliğinde örneklem belirlenerek, araştırma evreninden rastgele seçilen 127 kişi ile çevrimiçi anket yapılmıştır. Örneklemin bu sayıyla sınırlanmasının nedeni, yeni medya ortamında (online ortamda) yapılan çevrimiçi anket araştırmasının anlamlı sonuç verecek sayıda kısıtı belirlenmiş deneğe ulaştırılabilmesi ve sonuçları değerlendirebilme beklentisidir. Yüzün üzerinde kişiden oluşan veri kümesinden alınan veriler, internet öncesi dönemde sinema izleyicisi olan yetişkinlerin izleme alışkanlıklarındaki değişim hakkında tahmin yürütmeye imkan sağlayacak potansiyeldedir.

Araştırmanın soruları, Survey Monkey (surveymonkey.com) platformunda oluşturulan çevrimiçi anket formu ile web anketi olarak ilgili deneklere iletilmiştir. Sorularla ilgili ölçek testleri yapılmış ve alandaki yukarıda belirtilen araştırmalar incelenmiştir. Kullanıcı deneyimi yönüyle basit ve verimli bir arayüz olması ve analize imkan vermesi nedeniyle Survey Monkey platformu tercih edilmiştir. Sonuçlar yine aynı programın analiz ortamında değerlendirilerek raporlanmiştır.

Netflix'in bugünkü konumunu izleyici gözünden ortaya koyan araştırma, kültürel tüketimin arzu nesnesi haline gelmiş olan bu dijital yayın platformunun sinema sektörüne etkilerini tespit etme imkanı sağlamaktadır.

\section{Bulgular}

Yeni medya teknolojilerinin izleme alışkanlıklarına etkisi başlangıçta dijital televizyon yayınlarıyla ilgili görünse de film izleme deneyimindeki arayışlar, sinema filmlerini VCDDVD gibi cihazlardan sonradan izleme modelinden dijital platform aboneliklerine doğru evrilmiştir. Aslında bu yönelim tamamen sinema salonunda izleme edimine bir alternatif yaratmak değil; kaçırılan filmleri takip etmek, film çeşitliliği sağlamak gibi günlük yaşamda sinemaya daha çok yer açan davranışlardır. Günümüzde ortaya çıkan dijital platformlar ve Netflix'in, temelde sinemanın bu işlevini sürdürmek amaçlı oldukları varsayılabilir. Ancak gelinen aşamada, televizyon izleyicisi konumundaki kişilere dijitalleşmenin sağladığı imkanlar film alternatiflerini çoğaltırken, film izlemeye temel olan davranışı ya da ihtiyacı da değiştirmiştir. Aynı şekilde, sinema izleyicisi olan kitlenin motivasyonu halen sinemayı takip etmek olsa dahi, ev konforunda sinema deneyimini tercih eder hale gelmeleri, alışkanlıkların değişimine neden olmaktadır. Yapılan araştırmada, Netflix'in sinema izleyicisinin sinemaya gitme davranışını değiştirerek, evde izleme ortamlarının tercih edilir hale geldiği tezinin doğruluğu araştırılmaya çalışılmıştır.

Bu doğrultuda, sinema izleyicilerinin film izleme alışkanlıklarındaki değişimi tespit etmek üzere 30-55 yaş grubunda olan 127 kişi ile çevrimiçi anket yapılmıştır. İnternetin aktif olarak kullanılmadığı bir dönemde yetişen bu kişilerin, filmleri sinemada veya Netflix'te izleme tercihleri incelenmiştir. Bu veri, film izleme alışkanlıklarındaki değişimi ve sinemanın gelecekteki konumunu göstermesi açısından dayanak oluşturma potansiyeline sahiptir.

Katılımcıların \% 4,76'sı haftada bir kez, \% 5,56'sı iki haftada bir kez ve \% 45.24'ü ayda bir kez sinemaya gitmektedirler. Sinemaya nadiren gidenlerin oranı $\% 42,86$, hiç gitmeyenlerin ise \% 1,59'dur (Görsel 1). (Bu veriler pandemi dönemini kapsamamaktadır. Katılımcıların hemen hemen tamamı (\% 82,54) pandemi döneminde sinemaya gitmediklerini belirtmiştir.) 
S1 Sinemaya ne sıklıkla gider veya vizyon filmlerini takip edersiniz?

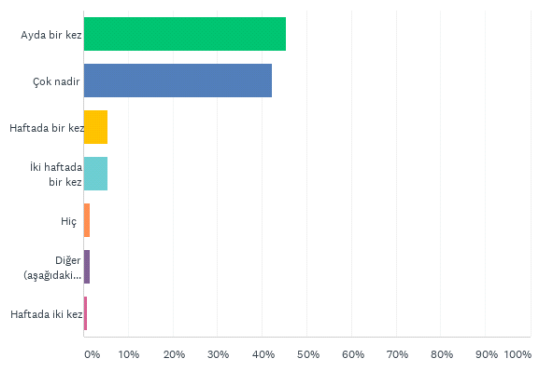

Görsel 1: Katılımcıların sinemaya gitme sıklı̆̆ı

Katılımcıların daha sık sinemaya gitmeme nedeni; \% 53,17 oranla vakit bulamama, $\%$ 27,78 bilet fiyatlarının yüksek olması, \% 11,11 birlikte gidecek kimsenin olmaması, \% 3,97'si sinemaların evine uzak olmasıdır. Fiziki şartlardan kaynaklı bu sebeplerin dışında, katılımcıların \% 9,52'si vizyon filmlerini takip etmediğini, \% 7,14'ü TV'deki filmleri izlemesinin yeterli olduğunu, \% 4,76' sı kalabalıktan hoşlanmadığını ve \% 0,79'luk bir kişi ise film izlemeyi sevmediğini ifade etmiştir. Diğer seçeneğindeki \% 11,11'lik kesimin yarısı olan \% 5,5'i sinemaya gitme miktarının yeterli olduğunu, diğer yarısı ise ev sinema sistemleri, dijital platformlar ve internet üzerinden evlerinde film izledikleri için gitmediklerini belirtmişlerdir.

Katılımcıların film izlemek için tercih ettikleri mecralar, \% 84,92 ile üyelik gerektiren dijital platformlar olarak görülmektedir. \% 36,51 internet web siteleri, \% 26,19 TV kanallarında yayınlananlar, \% 16,67 Youtube'da bulunanları izlerken, sinema salonlarında film izleme tercihi \% 21,43'tür (Görsel 2).

S3 Filmleri hangi mecradan/platformlardan izliyorsunuz?

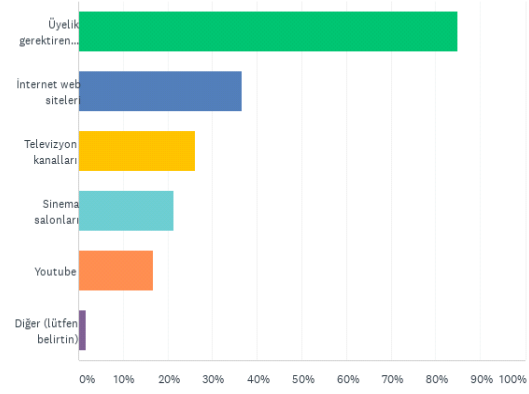

Görsel 2: Katılımcilarn film izlemek için tercih ettikleri mecralar

Büyük bir çoğunluğunun film izlemek için dijital platformları tercih ettikleri görülen katılımcıların, dijital platform üyeliklerinde ise \% 85,71 oranı ile Netflix başta gelmektedir (Görsel 3). Birden fazla platform üyeliğinin bulunduğu dijital ortamda Netflix'i takip eden oranlar; \% 25,40 Amazon Prime, \% 23,81 BeIN Connect, \% 13,49 BBC IPlayer, \% 11,90 Puhu TV, \% 11,90 Blue TV, \% 11,11 TV+, \% 7,94 Apple TV, \% 7,14 Youtube Prime, \% 7,14 Tivibu, \% 6,35 Mubi'dir. 


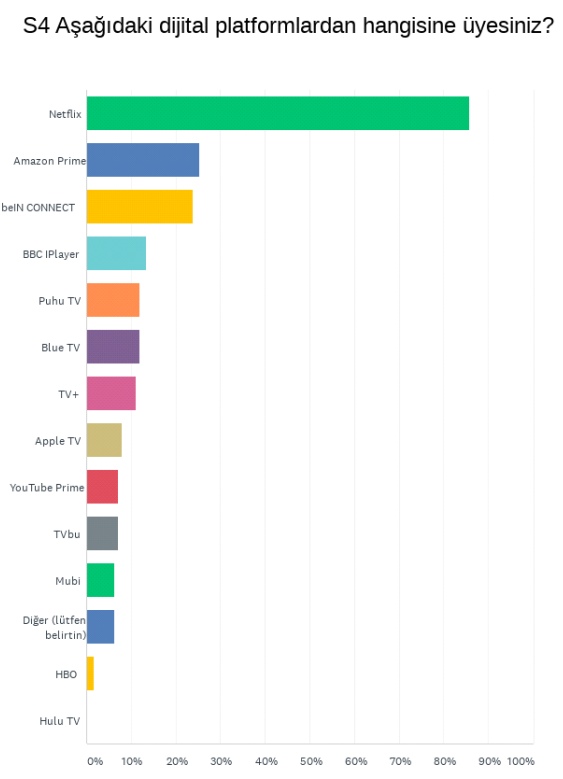

Görsel 3: Katılımcilarm üye oldü̆u dijital platformlar

Katılımcılar için izlenecek film seçiminde konu-tür-tavsiye ve oyuncu unsurlarının önde geldiği görülmektedir. Katılımcıların seçimini etkileyen unsurlarda \% 73,02 oranla filmi konusu, \% 66,67 türü, \% 51,59 oyuncuları tercih nedeniyken, \% 53,97'si tavsiye ve eleştirileri dikkate alarak film seçmektedir. Yönetmen \% 37,30, IMDB puanı \% 34,13, filmin aldığı ödüller $\%$ 26,19 etkendir. Filmleri yabancı veya yerli olmasına ve az sayıda da olsa ülke sinemalarını takibe göre izleyenler de vardır (Görsel 4).

S5 Film seçiminizde sizin için aşağıdaki seçeneklerin hangileri önemlidir?

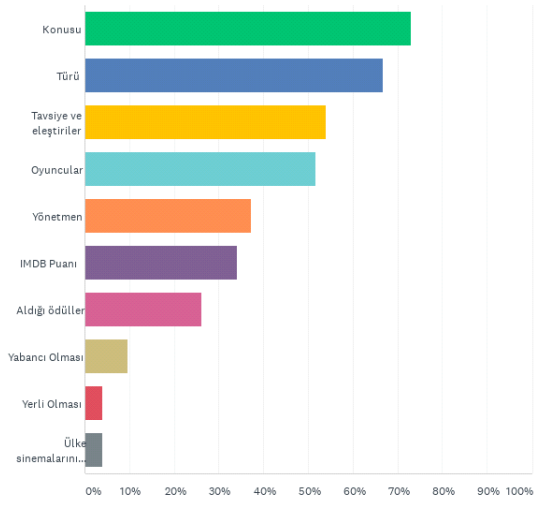

Görsel 4: Katılımcıların film seçimlerini etkileyen faktörler

İzleyiciler için dijital deneyim özelliklerinden \% 89,68 oranında reklamsız izleme, \% 62,70 oranında yüksek görüntü kalitesi ve \% 55,56 oranında da izlerken ara verip kaldığ 1 yerden izlemeye devam etmek önem taşımaktadır.

Katılımcıların Netflix'e üye olma sebepleri birden fazladır ve çeşitlilik göstermektedir. Netflix'e olan en önemli talebin \% 77 oranyla, izleme deneyiminin zamana bağlı olmama isteğinden kaynaklandığı anlaşılmaktadır. Ev rahatlığında ve zahmetsiz izleyebilme \% 72,22 ile bunu takip etmektedir. Sinema deneyimiyle ilgili olarak; Film seçeneklerinin çok olması $\%$ 61,9, sinemada kaçırılan filmleri izlemek \% 37,30, sinemaya göre ucuz olması \% 30,95, baz1 filmleri sinemada vizyona girişi ile aynı anda izleyebilme \% 20,63 oranında Netflix'e üye olmada önem taşımaktadır (Görsel 5). 
S7 Netflix'e üye olma sebepleriniz nelerdir?

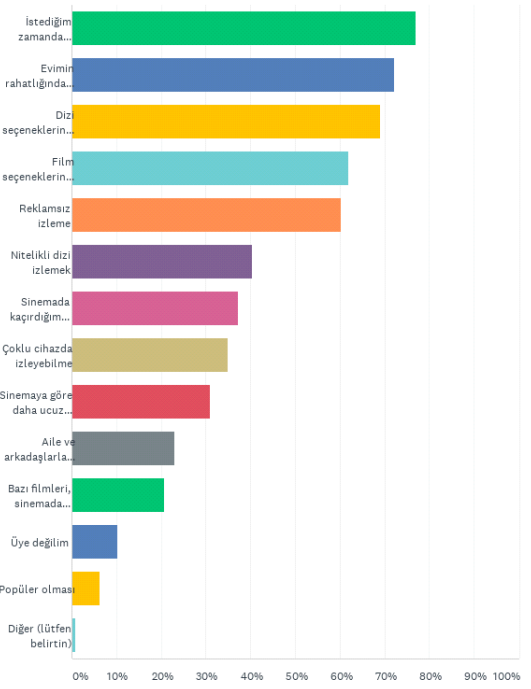

Görsel 5: Katılımcilarn Netflix'e üye olma sebepleri

Yapılan anketle elde edilmesi beklenen önemli göstergelerden biri olan "Vizyona yeni giren bir filmi her iki mecrada da gösterilirken, sinema salonunda mi yoksa Netflix'te mi izlemeyi tercih edersiniz?" sorusuna izleyenlerin verdiği yanıt kararsızlık göstermektedir. Katılımciların \% 35'sı sinema salonların tercih etmeye devam ederken \% 40'1 Netflix'i yeğlemektedir. Her ikisine de yakın duran \% 25'lik kesim, filmin görsel olarak niteliğine göre sinema salonuna yakın olabilecekken, ailece bir filme ödenecek değer gibi ekonomik hususlar devreye girdiğinde birden fazla bilet almaktansa ev ortamının rahatlığında, istediği zaman, daha çok kişiyle izlemeyi tercih ettiğini belirtmektedir (Görsel 6).

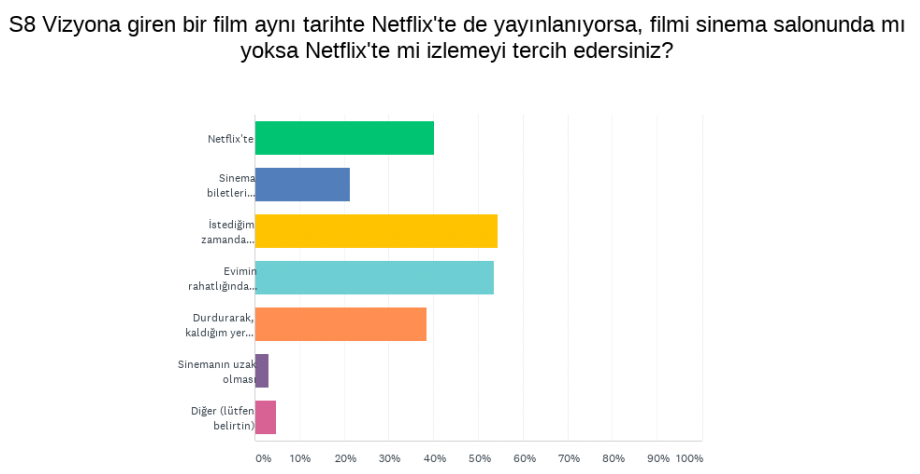

Görsel 6: Sinemayla eş zamanl yayınlanan vizyon filmini Netflix' te izleme nedenleri

Sinemayı tercih etme sebeplerinde öne çıkanlar ise \% 35,71 ile filme daha iyi konsantre olmak ve değer vermek, \% 31 sinema salonlarının yaşaması gerektiği düşüncesi, \% 27,78 beyaz perde (büyük ekran)'de izlemek ve ses kalitesi, \% 25 sinema ortamını sevmek, \% 15 ise sinema sanatına daha çok katkı sağladığını düşüncesi olarak sıralanmaktadır. Katılımcıların \% 11'i ise sinema salonlarında izlemenin kendilerini sosyalleştirdiğini ifade etmektedir (Görsel 7). 


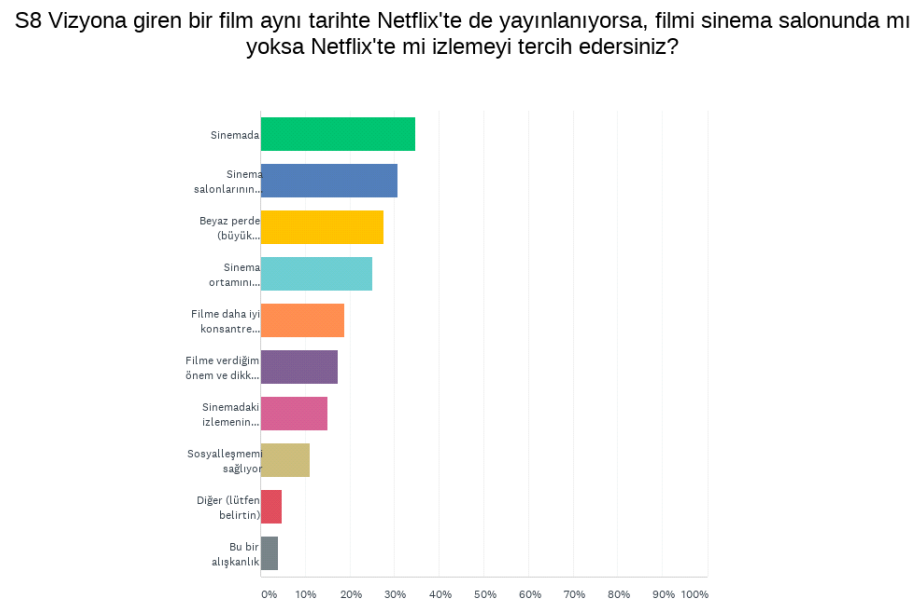

Görsel 7: Eş zamanl Netflix'te de yayınlanan vizyon filmini sinemada izleme nedenleri

Sinema filmlerinin vizyona tarihiyle aynı anda Netflix'te yayınlanmasının katılımcıların \% 35'i yanlış bulmakta, \% 23'ü ise doğru olduğunu düşünmektedir. \% 41,27'si ise kendisi için bir önemi olmadığını ifade etmiştir (Görsel 8).

S10 Sinema filmlerinin vizyona tarihiyle aynı anda Netflix'te yayınlanmasını nası karşillyorsunuz?

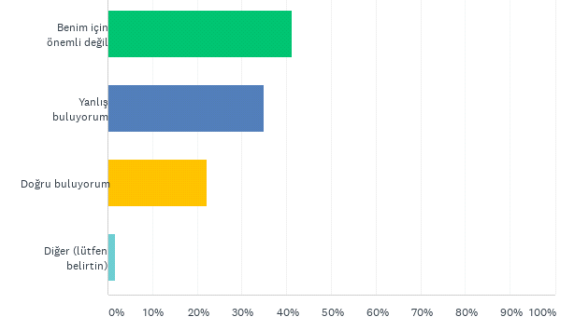

Görsel 8: Katılımcılarn, vizyon filmlerinin Netflix'te yayınlanması hakkında görüşleri

Araştırmaya katılanların \% 32'ü film festivallerini takip etmektedir. Takip edilen festivaller \% 20 oranıla İstanbul Film Festivali ve \% 14 oranıla If'dir. Katılımcıların \% 6,35'i Adana Altın Koza ve yine \% 6.35'i Antalya Altın Portakal film festivallerinin izleyicisi olduğunu belirtmiştir. Ancak film izleyicisi olan aynı kitlenin \% 67'sı herhangi bir festivali takip etmemektedir. Katılımclardan, festival izleyicisi olan ve olmayan her iki kesim de pandemi sürecinde etkin ve kullanımı kolay bir şekilde gerçekleştirilen online film festivallerine katılım sağlamamışlardır.

\section{Sonuç}

Yeni medya yayıncılığındaki gelişmelerle ortaya çıkan dijital platformlar ve özellikle dünya genelinde kullanıma açı olan Netflix, sinema sektörü ve film endüstrisinin yapım, dağıtım, gösterim süreçlerinde önemli değişimlere neden olmaktadır. Bu çalışmada, Netflix ile birlikte sinema izleyicilerinin davranışlarında meydana gelen değişim, yapılan bir çevrimiçi anket araştırmasıyla tespit edilmeye çalışılmıştır. Çeşitli filmlerin henüz sinemalarda gösterimdeyken eş zamanlı olarak Netflix'te yayınlanmasıyla alana müdahale eden Netflix'in, izleyicilerin kültürel tüketim nesnesi olarak sinemada film izleme davranışlarını değiştirdiği gözlemlenmektedir.Kendi yapımlarını üreterek film endüstrisinin üretim süreçlerine çeşitli bakış açılarına göre olumlu etki eden Netflix, bu filmlerin sinemada gösterilmemesi nedeniyle sinemanın dağıtım ve gösterim ayağını sekteye uğratmaktadır. 
Dünyanın önde gelen film festivallerinin, bağımsız sinemayı desteklemek ve sinemanın bir sanat eseri olarak sergilenme koşullarını muhafaza etmek üzere, çeşitli kurallar koyarak, öncelikle digital platformlarda yayınlanan filmlerin festivallere katılımını kabul etmedikleri görülmektedir. Sinema sektörünün dağıtım ve gösterim tarafının uğradığ1 ekonomik kayıp nedeniyle festivaller bu tedbirleri alırken; Netflix'in kendi yapımlarının festivallerde gösterilmesi talebi ise, bir sanat dalı olarak sinemanın onaylanma ihtiyacı ile sinema salonlarına bağımlı olmasının altını çizmektedir.

Yeni medya teknolojilerinin, ürettiği imkânlarla izleyiciyi pasif konumdan aktif konuma geçirdiği savı, konuya sosyolojik açıdan bakıldığında aslında alımlayıcının pasifliğinin artması şeklinde de yorumlanmaya açıktır. Sinemanın varolduğu 125 yılllık süreçte, televizyon, DVD gibi teknolojik gelişmelerin etkisiyle, çeşitli dönemlerde sinema salonlarının işlevi sorgulanagelmiştir. Günümüzde ise dijital platformların sinemaya etkisi tartışılmaktadır. Ancak araştırmadan elde edilen verilerin ortaya koyduğu gibi; sinemayı takip eden izleyici kitlenin, filmin niteliğine bağlı olarak dikkat ve özenle, büyük ekranda yüksek ses kalitesiyle film izleme isteği halen varlığını etkin şekilde sürdürmektedir. Sinema, gündelik yaşamında bir sosyalleşme aracı olarak varlığını korumaktadır. Film izleyicisinin diğer platformlarda film izleme edimini, halen sinema deneyiminin tamamlayıcısı olarak görmek mümkündür. Bu yönden bakıldığında Netflix'in sinema salonlarına bir alternatif değil, sinema izleyicisi için daha çok seçenek sunan bir platform konumunda olduğu bu araştırmayla bir kez daha ortaya konmuştur. Bu anlamda, Lefebre'ye göre şehirdeki gündelik yaşamın bir parçası olan sinema deneyiminin, halen bu özel konumunu koruduğu görülmektedir.

Ancak öte yandan, evde film izleme deneyiminin yarattığı konfor alanı, erişim kolaylığı, zamandan bağımsızlığı, ekonomik olarak uygunluğu, film seçeneklerinin çeşitliliği, beğenmediği filmi bir bedel ödemeden vazgeçebilme-değiştirebilme imkanı gibi gerçeklikler, sinemada izleme deneyiminin konumunu sarsmaya devam edecek potansiyel göstermektedir. Film üretim sürecinde, yeni bir pazar olarak yeni prodüksiyonlarla üretimin devamlılığını sağlayan ve bağımsız sinemayı destekleyen Netflix, çoklu cihazdan ve her yerden izlenebilmesi ile sinema sektörünün dağıtım ve gösterim ayağını dönüştürme potansiyeli taşımaktadır. 2020 yılından bu yana devam etmekte olan Covid-19 pandemisinin de etkisiyle uluslararası büyük film yapım şirketlerinin 2021 yılında vizyona giren yeni filmlerini sinemadaki gösterimleriyle eş zamanlı olarak çeşitli dijital yayın platformlarında gösterime sokması, sinemanın gösterim ayağındaki değişimin henüz yeni başladığını ortaya koymaktadır. Dijital platformlar, kültürel tüketicinin alışkanlıklarını kendi kullanım sürelerini doldurmadan çok daha önce değiştirmeye aday görünmektedir. Bu anlamda, tüketici motivasyonun arzu nesnesi olan Netflix'e yenilerinin eklenmeye devam etmesi mümkündür.

\section{Çıkar Çatışması Beyanı:}

Makale yazarı herhangi bir çıkar çatışması olmadığını beyan etmiştir.

\section{Kaynakça}

Althusser, L. (2014). Ideology and Ideological State Apparatuses (Notes Towards an Investigation). B. Brewster (translated from the French), London, New York: Verso.

Academy Foundation (2021, 12 Ocak). 93rd Academy Awards of Merit, Erişim adresi: www. oscars.org/sites/oscars/files/93aa_rules.pdf

Anadolu, B . (2020). Beyazperdeden Dijital Medyaya: Film İzleme Deneyiminin Değişimi Üzerine Bir Araştırma . OPUS Uluslararası Toplum Araştırmaları Dergisi , 16 (32) , 5075-5110 . DOI: $10.26466 /$ opus.796968 
Anghelcev, G., Sar, S., Martin, J., Moultrie, J. L. (2020). Is heavy binge-watching a socially driven behaviour? Exploring differences between heavy, regular and non-binge-watchers Journal of Digital Media \& Policy 11(3) DOI:10.1386/jdmp_00035_1

Barfield, C. (2018, 23 Mart). Steven Spielberg Thinks Netflix Films Are 'TV Movies' And Shouldn't Compete For Oscars, The Playlist, Erişim adresi: https:/ / theplaylist.net/stevenspielberg-netflix-oscars-20180323/

Berlinale (2021). 71. Internationale Filmfestspiele Berlin, General Guidelines for Submission and Participation, Erişim adresi: https://www.berlinale.de/en/film-entry/guidelines/ competition.html, https://www.berlinale.de/en/film-entry/guidelines/general-guidelines. html, https://www.berlinale.de/en/film-entry/guidelines/panorama.html

Baudrillard, J. (2005), Baştan Çıkarma Üzerine, A. Sönmezay (çev.), İstanbul: Ayrıntı.

Cuarón, A., Rodriguez G., Celis N. (Yapımc1), \& Cuarón, A. (Yönetmen). (2018). Roma [Sinema Filmi]. Meksika: Participant Media, Esperanto Filmoj.

Di $\square$ ker, C. (2019). Az Daha Fazladır: Dijital Seyir Platformlarının Tüketim Kültürü Açısından İzleyicilerin Seyir Alışkanlıklarına Olan Etkisi. Erciyes İletişim Dergisi, 1, 1-20.

Festival de Cannes (2021, 19 Ocak). The 74th Festival de Cannes - Submision of Films for Official Selection, Feature Films in Official Selection, Erişim adresi: https:/ / www.festival-cannes.com/ en/participer/rules?id=2

Karaduman, S. (2018). Yeni İletişim Teknolojileri ve Film İzleme Alışkanlıkları. Akdeniz Üniversitesi Sosyal Bilimler Enstitüsü Dergisi, 1(2), 163-174.

La Biennale Di Venezia (2021, 18 Ocak). 78th Venice International Film Festival - Regulations, Erişim adresi: www.labiennale.org/en/cinema/2021/regulations

Lefebvre, H. (1996). Writings on Cities, E. Kofman and E. Lebas (ed, trans.) Oxford, Massachusetts: Blackwell.

Lefebvre, H. (1998). Modern Dünyada Gündelik Hayat, I. Gürbüz (çev.), İstanbul: Metis.

Lefebvre, H., Régulier, C. (2004). Attempt at the Rhythmanalysis of Mediterrenean Cities, Rhythmanalysis - Space, Time and Everyday Life, S. Elden and G. Moore (ed, trans.), London, New York: Continuum.

Medin, B. (2018). Dijital Kültür, Dijital Yerliler ve Günümüzdeki Yeni Film Seyir Deneyimleri. Erciyes İletişim Dergisi, 5(3), 142-158.

Sennett, R. (2016). Kamusal İnsanın Çöküşü, S. Durak ve A. Yılmaz (çev.), İstanbul: Ayrıntı.

Netflix (2021, 19 Ocak). Netflix Investors, Q4-20 Shareholder Letter, Erişim adresi: https:// ir.netflix.net/ir-overview/profile/default.aspx

Osur, L. (2016). Netflix and the Development of the Internet Television Network, Surface, Syracuse University, New York, USA. Erişim adresi: https://surface.syr.edu/etd

Robins, J. (2018, 6 Haziran). Is Netflix Killing the Cinema? The Big Q - The University of Auckland, Erişim adresi: https:/ /www.thebigq.org/2018/06/06/is-netflix-killing-the-cinema/

TIFF (2020). Toronto International Film Festival, Rules\&Term, Erişim adres: https:/ / filmfreeway. $\mathrm{com} / \mathrm{TIFF}$ 
TÜİK (2020, 16 Haziran). Sinema ve Tiyatro İstatistikleri 2020, Erişim adresi: https://data. tuik.gov.tr/Bulten/Index?p=Sinema-ve-Tiyatro-Istatistikleri-2019-33622\#: :text

West, K. (December 13, 2013). “Unsurprising: Netflix Survey Indicates People Like To BingeWatch TV". Cinema Blend, Erişim adresi: https://www.cinemablend.com/television/ Unsurprising-Netflix-Survey-Indicates-People-Like-Binge-Watch-TV-61045.html 